\title{
The bacteriological quality of Hamburger patties from fast-food restaurants in Umuahia, Nigeria
}

\author{
*Edward, K.C. ${ }^{1}$, Ikpawho, E. ${ }^{1}$ and Ibekwe, V.I. ${ }^{2}$ \\ ${ }^{1}$ Department of Microbiology, Michael Okpara University of Agriculture, Umudike, Abia State \\ ${ }^{2}$ Department of Microbiology, Federal University of Technology, Owerri, Imo State
}

\begin{abstract}
Bacteriological analysis was conducted on sixteen samples of Hamburger patties from eight $(A-H) f$ ast-food restaurants in Umuahia. Eight of the samples were made of ground chicken $\left(A_{I}-H_{I}\right)$ and the other eight samples were made of ground beef $\left(A_{2}-H_{2}\right)$. Both $C 1$ and El samples gave the highest Escherichia coli count of $3.9 \mathrm{Log}_{10}$ cfu/g while sample $E_{2}$ gave the highest count of $3.7 \mathrm{Log}_{10}$ cfu/g amongst the beef samples. Samples $C_{1}$ and $C_{2}$ gave the highest Staphylococcal count of $3.95 \log _{10} \mathrm{cfu} / \mathrm{g}$ and $3.7 \log _{10} \mathrm{cfu} / \mathrm{g}$ respectively. The Salmonella count of $2.4 \log _{10} \mathrm{cfu} / \mathrm{g}$ was recorded by samples $C_{1}$ and $E_{2}$. The highest total aerobic plate count was $4.29 \mathrm{Log}_{10}$ cfu/g from sample E2 while the lowest was recorded by sample $D_{1}$ with a count of $3.3 \log _{10}$ cfu/g. Bacterial species isolated includes; S.aureus, E.coli, Bacillus spp, Proteus spp, Micrococcus spp, Pseudomonas spp and Salmonella spp. The presence of food-borne pathogens beyond the acceptable limit is of public health importance.
\end{abstract}

Keywords- Bacteriological quality, Fast-food, Hamburger patties, Umuahia

\section{Introduction}

From its birth in the 1940's in Southern California, the growth of fast food industry has been nothing less than astonishing. It has become so routine and so thoroughly mundane, that it is now taken for granted like brushing of teeth. In Nigeria, the fast food industry has grown tremendously in the $21^{\text {st }}$ century. Every major city in Nigeria is flooded with fast food restaurant. Worldwide, more money are now spent on fast food than on newspapers, magazines, books, movies, videos and recorded music combined.

Hamburger is one of the most popular fast foods, which carries considerable amount of meat all over the world. After production, Hamburger patties are mainly being kept cold or frozen until they were used in many restaurants (Ciftcioglu et al., 2008). The main raw material is minced beef, though fat and other ingredients may be included. (Fortuna et al., 2012; USDA/FSIS, 2012).

Microbial pathogen control in hamburger patty production poses several challenges. Ground meats are a troublesome source of food borne infection. Intensive handling and complex preservation issues in preparation promote pathogen growth and transmission (Fortuna et al., 2012). Grinding operations typically take raw beef trimmings from multiple sources and mix these inputs together to make patties. Meat trimmings may carry high pathogenic loads because of how they are being handled and because they have multiple exposed surfaces. The grinding operation itself disperses pathogens present on the trimmings throughout the ground product and there is opportunity for those pathogens to multiply in the subsequent supply chain.

The primary method of destroying pathogens in hamburger patties is to cook them to a proper internal temperature (Nester et al., 2008). USDA recommend slowest heating points for hamburger patties of $71.1^{\circ} \mathrm{C}$ $1160^{\circ} \mathrm{F}$ (Clavero et al.,1998; USDA/FSIS, 2012) or $70^{\circ} \mathrm{C}$ for $2 \mathrm{~min}$ (FDA, 2007). Ground poultry should be cooked to an internal temperature of $74^{\circ} \mathrm{C}\left(165^{\circ} \mathrm{C}\right)$. According to USDA/FSIS (2012), re-heated patties should be cooked to an internal temperature of $73.9^{\circ} \mathrm{C}\left(165^{\circ} \mathrm{F}\right)$. Premature browning is a food safety issue; because hamburger patties appear fully cooked (brown), even though they have not reached an internal temperature sufficient to kill pathogens (Hague et al., 1994).

Although research indicates that food safety is not a factor which influences the public's choice when selecting an eating establishment (Leach et al., 2001), the detection and characterization of pathogens in food is very important in the control and prevention of food poisoning outbreaks. This work is therefore aimed at determining the microbiological quality of Hamburger patties from fast food restaurants in Umuahia, Nigeria.

Sample collection:

\section{Materials And Methods}

Sixteen Hamburger patties \{eight of chicken $\left(\mathrm{A}_{1}-\mathrm{H}_{1}\right)$ and eight of beef $\left.\left(\mathrm{A}_{2}-\mathrm{H}_{2}\right)\right\}$ were bought from eight fast food restaurants in Umuahia, the samples were immediately transported to the laboratory in well wrapped, clean, sterile aluminum foil.

Isolation and enumeration of microorganisms 
Nutrient agar, Salmonella shigella agar, Mannitol Salt agar, Eosin Methylene blue agar, were prepared according to manufacturer's instruction and sterilized by autoclaving at $121^{\circ} \mathrm{C}$ for $15 \mathrm{mins}$. Hamburger patties were analyzed after aseptic removal of the bread/bun component of the hamburgers. 10grams of each patty was blended in a sterile blender with $90 \mathrm{mls}$ of normal saline for two minutes. 10 fold serial dilutions were prepared and $1 \mathrm{ml}$ of the relevant dilutions was inoculated onto duplicate plates of the already prepared media using the pour plate technique. The plates were then incubated at $37^{\circ} \mathrm{C}$ for $24-48 \mathrm{~h}$ and examined for colony formation.

After incubation, colonies were counted using a colony counter (Gallencamp) and then the colonial counts recorded as cfu/g were converted to $\log 10 \mathrm{cfu} / \mathrm{g}$. Pure cultures of isolates were obtained by sub-culturing in fresh medium using the streak plate method.

Identification of isolates

Bacterial isolates were identified based on standard microbiological cultural, morphological and biochemical characteristics as described by Cowan and Steel, (1965), Prescott et al. (1996) and Cheesebrough, (2006). The characteristics and biochemical tests include; Gram reaction, endospore staining, catalase, urease, coagulase, citrate, oxidase, sugar fermentation, methyl red-Voges proskauer and indole tests.

Table 1: Microbial counts for organisms of public health interest in burger patties

\begin{tabular}{|c|c|c|c|c|}
\hline \multirow{2}{*}{ Samples } & \multicolumn{4}{|c|}{ Microbial counts $\left(\log _{10} \mathrm{cfu} / \mathrm{g}\right)$} \\
\hline & Total aerobic plate count & E.coli & Staphylococcus & Salmonella \\
\hline $\mathrm{A} 1$ & 4.10 & 3.58 & 3.50 & 0 \\
\hline B1 & 3.60 & 2.80 & 2.84 & 0 \\
\hline $\mathrm{C} 1$ & 4.20 & 3.90 & 3.95 & 2.40 \\
\hline $\mathrm{D}_{1}$ & 3.30 & 2.70 & 2.80 & 0 \\
\hline $\mathrm{E}_{1}$ & 4.50 & 3.90 & 3.60 & 2.30 \\
\hline $\mathrm{F}_{1}$ & 3.60 & 2.78 & 2.80 & 0 \\
\hline $\mathrm{G}_{1}$ & 3.40 & 2.90 & 2.84 & 0 \\
\hline $\mathrm{H}_{1}$ & 3.70 & 2.80 & 2.97 & 0 \\
\hline $\mathrm{A}_{2}$ & 4.00 & 3.52 & 3.43 & 0 \\
\hline $\mathrm{B}_{2}$ & 3.75 & 2.90 & 2.97 & 0 \\
\hline $\mathrm{C}_{2}$ & 3.75 & 3.50 & 3.70 & 0 \\
\hline $\mathrm{D}_{2}$ & 3.50 & 2.87 & 2.90 & 0 \\
\hline $\mathrm{E}_{2}$ & 4.29 & 3.70 & 3.60 & 2.40 \\
\hline $\mathrm{F}_{2}$ & 3.50 & 2.85 & 2.90 & 0 \\
\hline $\mathrm{G}_{2}$ & 3.60 & 2.70 & 2.80 & 0 \\
\hline $\mathrm{H}_{2}$ & 3.50 & 2.78 & 2.70 & 0 \\
\hline APHA acceptable limit & $\square 5.00 \log _{10} \mathrm{cfu} / \mathrm{g}$ & $\square 2.00 \log 10 \mathrm{cfu} / \mathrm{g}$ & $\square 2.00 \log 10 \mathrm{cfu} / \mathrm{g}$ & $0 / 25 \mathrm{~g}$ \\
\hline
\end{tabular}

Key:A1-H1=Chicken Burger, A2-H2=Beef Burger, APHA=American Public Health Association

Table 2: Percentage occurrence of bacterial isolates in burger patties

\begin{tabular}{|c|c|c|c|c|c|c|c|c|}
\hline $\begin{array}{l}\text { Isolates } \\
\text { Samples }\end{array}$ & Bacillus & Staphylococcus & Pseudomonas & Proteus & Micrococcus & Salmonella & E.coli & percentage \\
\hline A1 & - & + & + & + & - & - & + & $57 \%$ \\
\hline B1 & _ & + & _ & _ & _- & _- & + & $29 \%$ \\
\hline $\mathrm{C} 1$ & + & + & + & + & + & + & + & $100 \%$ \\
\hline $\mathrm{D}_{1}$ & _- & + & _- & _- & _- & _ & + & $29 \%$ \\
\hline $\mathrm{E}_{1}$ & + & + & + & + & + & + & + & $100 \%$ \\
\hline $\mathrm{F}_{1}$ & _- & + & _- & + & + & _ & + & $57 \%$ \\
\hline $\mathrm{G}_{1}$ & _ & + & _ & + & + & _ & + & $57 \%$ \\
\hline $\mathrm{H}_{1}$ & _- & + & _ & + & - & _ & + & $43 \%$ \\
\hline $\mathrm{A}_{2}$ & + & + & _ & + & _- & _ & + & $57 \%$ \\
\hline $\mathrm{B}_{2}$ & - & + & _ & + & _- & _ & + & $43 \%$ \\
\hline $\mathrm{C}_{2}$ & + & + & - & - & + & - & + & $57 \%$ \\
\hline $\mathrm{D}_{2}$ & - & + & - & - & - & - & + & $29 \%$ \\
\hline $\mathrm{E}_{2}$ & - & + & + & + & + & + & + & $86 \%$ \\
\hline $\mathrm{F}_{2}$ & + & + & _ & _ & + & _ & + & $57 \%$ \\
\hline $\mathrm{G}_{2}$ & _ & + & - & + & + & _ & + & $57 \%$ \\
\hline $\mathrm{H}_{2}$ & + & + & + & - & - & - & + & $57 \%$ \\
\hline$\%$ & $38 \%$ & $100 \%$ & $31 \%$ & $63 \%$ & $50 \%$ & $19 \%$ & $100 \%$ & \\
\hline
\end{tabular}

Key: $+=$ present, $\_=$absent 


\section{Discussion}

Most of the burger patties analyzed posed zero to low microbial risks i.e they were within acceptable limits ( $\square 5.0 \log _{10} \mathrm{cfu} / \mathrm{g}$ for total aerobic plate counts, $\square 2.0 \log _{10} \mathrm{cfu} / \mathrm{g}$ for S.aureus and E. coli count and 0/25g for Salmonella (APHA, 2004). However, the bacterial quality of the samples also varied with the fast food restaurants, with high microbial load from two of the fast-food restaurants ' $\mathrm{C}$ and $\mathrm{E}$ ' ranging from 3.9 Log10 cfu/g -4.5 Log10cfu/g (TABLE1). The high microbial load, though, within acceptable limits in the samples can be attributed to what Johnston and Tompskins (1992) described as some low level of contamination which occurs during handling, packaging or serving of cooked products on surface of the product from equipment's and food handlers.

Growth of Salmonella was found in three samples, fast-food restaurants $\mathrm{C}_{1}, \mathrm{E}_{1}$ and $\mathrm{E}_{2}$ (TABLE1). $\mathrm{E}_{1}$ recorded $2.3 \mathrm{Log} 10 \mathrm{cfu} / \mathrm{g}$, while sample $\mathrm{E} 2$ and $\mathrm{C} 1$ recorded $2.4 \mathrm{Log} 10 \mathrm{cfu} / \mathrm{g}$ respectively. Improper preparation and handling of foods at food service establishments are primary factors in Salmonella outbreaks (Jay, 1992). S. aureus recorded a highest count of $3.95 \mathrm{Log} 10 \mathrm{cfu} / \mathrm{g}$ from fast food $\mathrm{C}_{1}$, which might be attributed to low level of food hygiene practices (TABLE1). The presence of small number of $S$. aureus is not uncommon (Adams and Moss, 2000). Human contact with cooked food invariably introduces $S$. aureus of levels $10^{1}$ or $10^{2}$ to many sample units, (Surkiewics, et al., 1973), such levels are harmless but offer sufficient inoculums for growth.

Sample $\mathrm{C}_{1}$ and $\mathrm{E}_{1}$ recorded the highest counts of $E$. coli which was $3.9 \mathrm{Log} 10 \mathrm{cfu} / \mathrm{g}$ (TABLE1). Unavoidable contamination usually will add coliforms of level $10^{1}$ or $10^{2}$ per gram to the surface of the product (Johnson and Tompskins, 1992). The presence of coliforms on the surface of properly cooked meat products indicate post process contaminations and warrants investigation of the condition of preparation (Speck, 1976). Also human contacts may sometimes introduce E. coli.

Other organisms like, Proteus, Micrococcus, Pseudomonas and Bacillus, were found in their small numbers during the course of the research work (TABLE2). These organisms might be associated with the environment According to Killinger et al., (2000), consumers often believe that a brown internal color indicates that a patty is fully cooked. The food safety and inspection service, the food and drug Administration and the centre for disease control and prevention recommend that consumers use a thermometer to cook hamburgers to $160^{\circ} \mathrm{F}\left(71^{\circ} \mathrm{C}\right)$ USDA/FSIS (1998a) with no reference to internal color.

\section{Conclusion}

From this research it is evident that eating of hamburger patties might pose a health risk even though as yet there have not been any report of any outbreak assigned to its consumption in Nigeria. However, to ensure the safety and health of their customers, fast-food restaurants should inculcate food safety practices and habits in their staff and food processing. The critical control points to preventing food borne illness such as preventing cross - contamination from the raw products to ready to eat foods, using adequate time and temperatures for cooking $\left(160^{\circ} \mathrm{F}\right.$ or $\left.71^{\circ} \mathrm{C}\right)$, avoiding recontamination after cooking, by surfaces previously contaminated with the raw meat, and properly chilling and storing meat after mincing should be emphasized. Food handlers should also be trained on hygienic food handling practices and safety.

\section{References}

[1] N.M.D. Ahmed, E. Conner and D.I. Huffman, Heat resistance of Escherichia coli 0157:H7 in meat and poultry as affected by poultry composition, Journal of Food Science, 60(3), 1995, 600-610.

[2] M.R.S. Clavero, L.R. Beauchat and M.P. Doyle, Thermal inactivation of Escherichia coli 0157:H7 isolated from ground beef and bovine faeces, suitability of media for enumeration. Journal of Food Protection, 61(4), 1998, 285-289.

[3] S.T. Cowan, and K.J. Steel, Manual for identification of bacteria $2^{\text {nd }}$ ed. (London: Cambridge University Press, 1965), pp163-169

[4] M.A. Hague, K.E. Warren, M.C. Hunt, D.H. Kropf, C.L. Kastner, S.L. Stroda and D.E. Johnson, End point temperature, internal cooked color and expressible juice color relationships in ground beef patties. Journal of Food Science, 5, 1994, 465-470.

[5] J.M. Jay, Modern Food Microbiology (New York :Chapman and Hall, 1992) pp 507-526

[6] R.W. Johnstons and R.B. Tompskins,. Meat and poultry products. Compendium of methods for the microbiological examination of foods. (Washington, D.C: American Public Health Association, 1992), pp821-835

[7] K.M. Killinger, M.C. Hunt, R.E. Campbell and D.H. Kropf, Factors affecting premature browning during cooking of storepurchased ground beef, Journal of Food Science, 65(4), 2000, 585-587.

[8] J. Leach, H. Mercer, G. Stew and S. Denyer, Improving food hygiene standards- a customer focused approach, British Food Journal, 3(4), 2001, 238-252.

[9] E.W. Nester, D.G.C. Anderson, R. Evans and M.T. Nester, Microbiology: Human perspective $5^{\text {th }}$ ed.( New York: McGraw-Hill Co Inc., 2008) Pp210-808.

[10] L.M. Prescott, J.P. Harley, and D.A. Klein, Microbiology Laboratory Exercise $3^{\text {rd }}$ ed, (New York: Block Dot Inc. 1996) pp40-420

[11] B.F. Surkiewicz, M.E. Harris and R.W Johnson, Bacteriological Survey of frozen meat and gravy produced at establishments under Federal inspection, Applied Microbiology, 26(4), 1973, 574-576.

[12] G. Ciftcioglu,O.O. Arun, A.Vural, A. Aiydin and H. Aksu, ()Survival of E.coli 0157:H7 in minced meat and Hamburger patties, Journal of Food, Agriculture and Environment, 6(1), 2008, 24-27.

[13] Speck, M.L.. Meat and poultry products. Compendium of Methods for the microbiological examination of food. (Washington, D.C.: American Public Health Association, 1976) pp540-548

[14] USDA/FSIS, Food safety Information, Ground Beef and food safety (USDA/FSIS, 2012).

[15] FDA, revised guidance on safe cooking of burger, (FDA,2007)

[16] J.L. Fortuna, E.Rosendo do Nascimento and R.M. Franco, detection of Salmonella spp in Hamburgers: a comparison between modified standard and salmocyst method, Internet Journal of Food safety, 14, 2012, 104-112. 